
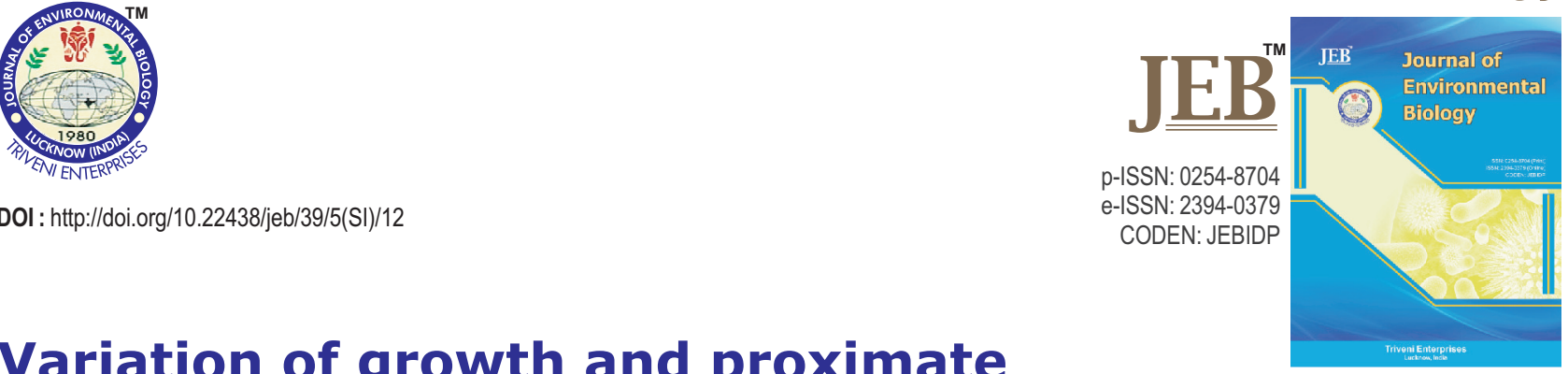

\title{
Variation of growth and proximate composition in Portunus pelagicus juveniles fed with selected feeds in recirculating aquaculture system (RAS)
}

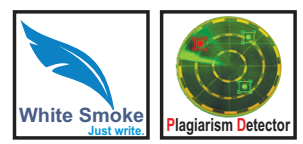

\section{Authors Info}

S.M.S. Kohinoor, A. Arshad*, S.M.N. Amin, Mohd. S. Kamarudin and M.A. Sulaiman

Department of Aquaculture, Faculty of Agriculture, Universiti Putra Malaysia, 43400 UPM Serdang, Selangor Darul Ehsan, Malaysia

${ }^{*}$ Corresponding Author Email azizar.upm@gmail.com

Key words

Captive culture

Growth rate

Portunus pelagicus

Survival rate

Water quality

Publication Info

Paper received : 15.07 .2017

Revised received : 20.10 .2017

Re-revised received : 28.11 .2017

Accepted : 28.12.2017

\section{Abstract}

Aim: The experiment was conducted to determine the suitability of using scad fish, Acetes shrimp and common squid for the direct and indirect application as diets for the juvenile rearing of the blue swimming crab Portunus pelagicus.

Methodology: A total of 54 crab juveniles with an initial weight of $2.46 \pm 0.94 \mathrm{~g}$ were randomly stocked in triplicate at 6 crabs per $60 \mathrm{I}$ tank $\left(0.26 \mathrm{~m}^{2}\right)$ experimental units and fed twice daily with three different types of feed namely scad fish, squid tissue and frozen Acetes shrimp for a period of 31 days.

Results: At the end of the trail, ammonia and nitrite-nitrogen compound were significantly higher in Acetes shrimp fed group. It is found that final body weight $(\mathrm{g})$ of $P$. pelagicus was significantly higher when fed with squid, however no significant differences were noticed between scad fish and Acetes shrimp fed groups. The whole body proximate composition was similar in all the diet fed individuals except the level of lipid which was higher in squid compared to scad fish and Acetes shrimp. Significantly $(p<0.05)$ better food conversion ratio (FCR) was observed in juvenile crab fed with squid even though scad fish possessed the highest crude protein of $83.33 \%$.

Interpretation: Overall, the results suggested that squid meal could be recommended for $P$. pelagicus juvenile culture. Hence, squid meal may be incorporated in crab artificial diet as protein source to attain better survival and growth.

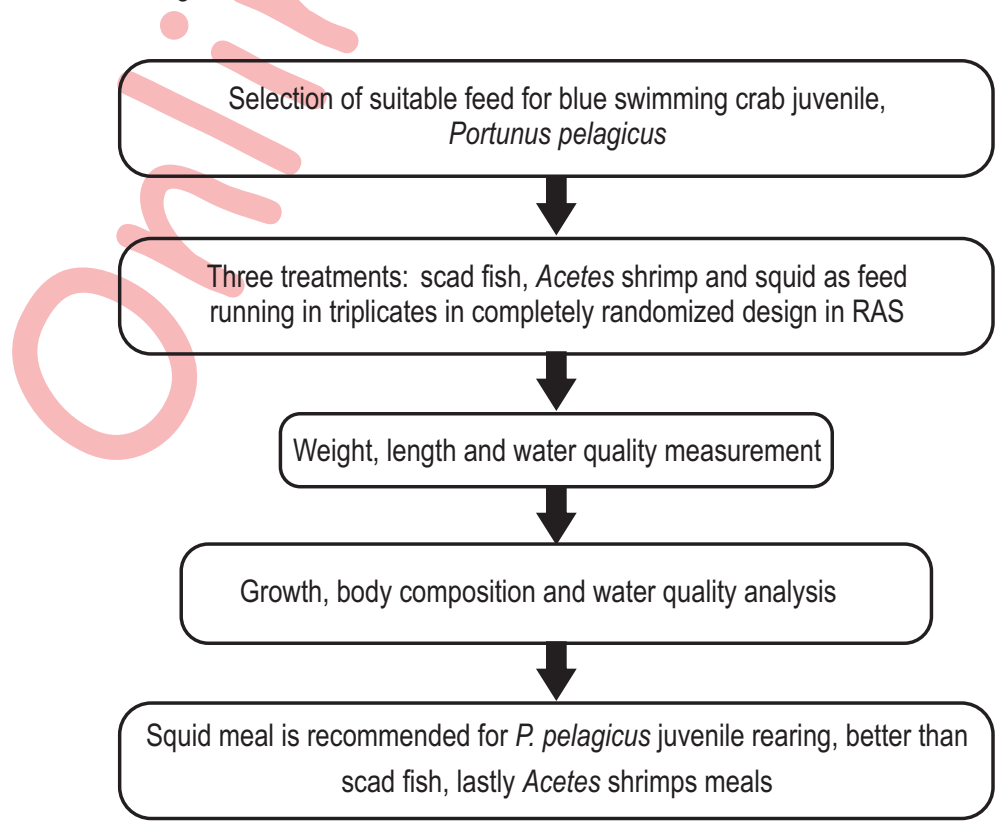




\section{Introduction}

Portunus pelagicus is mainly a bottom feeder carnivorous crustacean and feeds on different types of benthic fauna and flora within its habitat (Wu and Shin, 1998). They dwell in a wide range of shallow coastal habitats such as muddy and sandy bottoms, seagrass and algal beds, and show wide range of habitat complexity (Asphama et al., 2015). Blue swimming crabs are considered as important species for fishers of lower income group that depends on this crab's fishery (Asphama et al., 2015). In Malaysia, it is the top most popular marine crab species and fetches high price in the market. As a delicacy, they have a great demand in local and international markets, and recognized as a high-protein and low lipid food containing $21.54-22.64 \%$ protein, $0.81-1.21 \%$ total lipid (Gokoolu and Yerlikaya, 2003) and good sources of fatty acids (Deniz, 2016). It also serves as an important member of food chain due to its relationship with various subtrophic levels, thus playing a significant role in the ecosystem (Hall et al., 2006).

Food and feeding is one of the most essential factors influencing the growth performance of the blue swimming crabs. Several studies on feeding and diet of $P$. pelagicus have been conducted in various countries of the world such as natural diets (Hyslop, 1980; Ikhwanuddin et al., 2014), diet changes (Arshad et al., 2002), food habits (Chande and Mgaya, 2004), food and feeding habits (Josileen, 2011), feeding ecology (Kunsook et al., 2014) and feed acceptability (Tina and Darumas, 2014). However, there is very little information available regarding the effect of different selected fresh diets on variation of growth and proximate composition in $P$. pelagicus juveniles in RAS system. Thus, the study was conducted to evaluate the growth performance of $P$. pelagicus juvenile using different types of fresh diets.

\section{Materials and Methods}

Experimental site: This experiment was carried out at the hatchery complex in the Marine Science Center of UPM, Port Dickson, Negeri Sembilan, Malaysia.

Source and rearing of experimental crabs: Hatcheryproduced healthy crab instar (C1) with intact appendages was used for the present experiment; and nursery rearing was performed in three rectangular tanks $\left(3 \mathrm{~m}^{3}\right)$. In order to minimize cannibalism between crabs, sandy substratum were used at the bottom and tanks were filled with aerated seawater up to a level of $50 \mathrm{~cm}$ depth. The animals were nursery reared for 30 days. The crabs received UV treated seawater (32 - 33 ppt) with a daily water exchange of $20 \%$. Water $\mathrm{pH}$ was maintained at a range between 7.5 and 8.0 using calcium carbonate whenever necessary. Diffused aeration was provided to maintain the dissolved oxygen (DO) level in each nursery tank. During the culture period, the first crab instars were fed at $30 \%$ body weight with a mixed diet containing scad fish, squid and shrimp meal
(Feed No. 5002, C.P. Aquaculture Private Limited) twice a day in feeding trays. At the end of 30 days period of nursing, the crabs attained nearly $25 \mathrm{~mm}$ carapace width. The healthy juvenile with intact appendages was harvested for further growth performance trial.

Design of experiment: The feeding trial was performed in 9 plastic basins $\left(0.26 \mathrm{~m}^{2}\right)$ with a water volume of approximately $60 \mathrm{I}$. Each basin was attached to a recirculation bio-filtering system. Each basin contained a $10 \mathrm{~cm}$ layer of sea sand at the bottom and $15 \mathrm{~cm}$ of free water surface above the sand layer. The sandy substratum was adjusted to the culture condition for 15 days before starting the experiment.

Stocking: In this study, a total of 54 juvenile (C30) crabs were used and each basin was stocked with six healthy intact juvenile crabs $\left(24 / \mathrm{m}^{2}\right)$ with mean initial wet weight of $2.46 \mathrm{~g}$, carapace width $31.05 \mathrm{~mm}$ and carapace length $15.74 \mathrm{~mm}$.

Experimental feeds: In this experiment, three types of foods such as scad fish, squid (Loligo sp.) and Acetes shrimps were used and these diets were chopped into approximately $1 \mathrm{~mm}$ particle size. Three replicates for each treatment were randomly assigned. All the feeds were stored in freeze and thawed before being fed to the juveniles. Association of Official Analytical Chemists (AOAC, 1997) method was followed to analyze the proximate composition of the used foods (Table 1).

Feeding: The feeding amount was applied for 3 days (before starting the experiment) at $15 \%, 20 \%$ and $25 \%$ of the total body weight of wet weight basis to determine the exact feeding required per day. Twenty percent was shown the best feed consumed performance than those of other two percentages. Subsequently, during the experimental period, the selected fresh frozen diets were fed for the first 15 days at $20 \%$ of their total wet body weight and adjusted by $10 \%$ until the end of the culture period (Baliao et al., 1999). The blue crabs were fed manually at early morning (9.00 a.m.) and late afternoon ( 6.00 p.m.) daily.

Water quality parameter: The water quality parameters taken for analysis are salinity, temperature, $\mathrm{pH}$ and dissolved oxygen, they were measured once a week with YSI 556 Multi-probe (USA); ammonia-nitrogen and nitrite-nitrogen were measured using a commercial kit (API pharmaceutical test kit).

Growth trials: Before stocking the crabs in the culture tank, the initial average body weight $(\mathrm{g})$, carapace length $(\mathrm{mm})$ and width $(\mathrm{mm})$ were recorded. Body weight, carapace width and length of $P$. pelagicus were measured fortnightly until the end of culture period using a digital balance $(0.01 \mathrm{~g})$ and a digital caliper $(0.01$ $\mathrm{mm}$; Mitutoyo, Japan), respectively. At the end of experiment, the final body weight gain (\%), specific growth rate (SGR) (\%), survival rate $(\%)$, feed conversion ratio (FCR), feed efficiency $(\mathrm{FE})(\%)$ and protein efficiency ratio (PER) of the P. pelagicus 
were calculated for different treatments. An the end of the experiment, few crabs were randomly selected and stored at -20 ${ }^{\circ} \mathrm{C}$ for the whole-body proximate composition analysis.

Whole-body proximate composition: Biochemical analysis was carried out following the standard procedures of AOAC (1997). Crude protein $(N \times 6.25)$ was determined using the Kjeldahl method after an acid digestion using protein analyzer Unit (2300 Kjeltec Analyzer Unit, Foss Tecator). Crude lipid was determined by petroleum ether extraction using a Soxtec system (Soxte System 2050 Foss Tecator). Crude fiber was determined by utilizing fibertec system. Moisture was determined by oven drying at $105{ }^{\circ} \mathrm{C}$ for $24 \mathrm{hr}$; and ash was determined by muffle furnace at $600^{\circ} \mathrm{C}$ for $4 \mathrm{hr}$.

Calculations and statistical analysis : Finally, data analyses were performed using the following standard formula:

Final body weight (g) - Initial body weight (g)

$$
\text { Weight gain }(\%)=\frac{\text { Initial body weight }(\mathrm{g})}{\times 100 \text { (Tina and Darumas, 2014) }}
$$

Final body weight (g) - Initial body weight (g)

$$
\operatorname{SGR}(\%)=\frac{\text { Culture period (day) }}{x 100 \text { (Ikhwanuddin et al., 2012) }}
$$

$$
\begin{gathered}
\mathrm{FCR}=\frac{\text { Total quantity of feed consumed }(\mathrm{gm})}{\begin{array}{c}
\text { Total weight }(\mathrm{gm}) \\
(\text { Maheswardue et al., 2008) }
\end{array}} \\
\text { PER }=\frac{\text { Final wet weight }(\mathrm{gm})-\text { Initial wet weight }(\mathrm{gm})}{\begin{array}{c}
\text { Ingested protein } \\
(\text { Estefanell et al., 2011) }
\end{array}}
\end{gathered}
$$

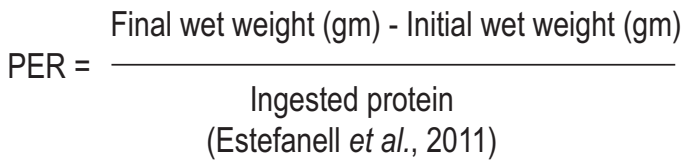

Final wet weight (gm) - Initial wet weight (gm)

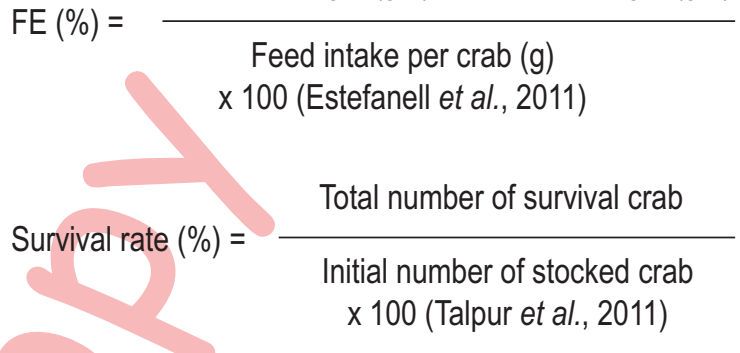

Protein retention $\%=(\%$ final body protein content $x$ final body weight) - (\%initial body protein content $x$ initial body weight) / total feed $\mathrm{x} \%$ protein diet $\times 100$ (Ishak et al., 2016)

Lipid retention $\%=(\%$ final body lipid content $x$ final body weight $)-$ (\% initial body lipid content $\mathrm{x}$ initial body weight) / total feed $\mathrm{x} \%$ lipid diet $\times 100$ (Ismail et al., 2016)

Table 1 : Proximate composition of different diets given to Portunus pelagicus juvenile ( $\%$ on a dry basis)

\begin{tabular}{llll}
\hline Proximate composition & T1 (Scad fish) & T2 (Squid) & T3 (Acetes shrimp) \\
\hline Moisture (\%) & $72.70 \pm 0.47$ & $74.47 \pm 2.02$ & $77.92 \pm 1.63$ \\
Protein (\%) & $83.33 \pm 1.01$ & $75.41 \pm 0.46$ & $56.74 \pm 0.94$ \\
Lipid (\%) & $4.76 \pm 0.35$ & $3.14 \pm 0.15$ & $3.27 \pm 0.02$ \\
Fiber (\%) & $6.72 \pm 0.19$ & $8.33 \pm 0.14$ & $4.69 \pm 0.11$ \\
Ash (\%) & $4.52 \pm 0.09$ & $4.56 \pm 0.03$ & $9.92 \pm 0.41$ \\
\hline
\end{tabular}

${ }^{*}$ Moisture (\%) on as weight basis

Table 2: Water quality data taken on weekly basis for culturing blue swimming (Portunus pelagicus) crab juvenile fed with selected feed for 31 days

\begin{tabular}{llll}
\hline & & Water quality parameters & \\
\cline { 2 - 4 } Treatment & T1 (Scad fish) & T2 (Squid) & T3(Acetes shrimp) \\
\hline Water temperature $\left({ }^{\circ} \mathrm{C}\right)$ & $26.58 \pm 0.35^{\mathrm{a}}$ & $26.75 \pm 0.50^{\mathrm{a}}$ & $26.46 \pm 0.40^{\mathrm{a}}$ \\
Dissolved oxygen $\left(\mathrm{mgl}^{-1}\right)$ & $6.17 \pm 0.26^{\mathrm{a}}$ & $6.24 \pm 0.35^{\mathrm{a}}$ & $6.16 \pm 0.30^{\mathrm{a}}$ \\
Salinity $(\mathrm{ppt})$ & $31.23 \pm 0.13^{\mathrm{a}}$ & $31.19 \pm 0.11^{\mathrm{a}}$ & $31.17 \pm 0.12^{\mathrm{a}}$ \\
$\mathrm{pH}$ & $7.88 \pm 0.03^{\mathrm{a}}$ & $7.91 \pm 0.04^{\mathrm{a}}$ & $7.90 \pm 0.4^{\mathrm{a}}$ \\
Ammonia-nitrogen $\left(\mathrm{mgl}^{-1}\right)$ & $0.33 \pm 0.12^{\mathrm{b}}$ & $0.27 \pm 0.13^{\mathrm{b}}$ & $1.21 \pm 0.50^{\mathrm{a}}$ \\
Nitrite-nitrogen $\left(\mathrm{mgl}^{-1}\right)$ & $0.02 \pm 0.07^{\mathrm{b}}$ & $0.04 \pm 0.10^{\mathrm{b}}$ & $0.63 \pm 0.50^{\mathrm{a}}$ \\
\hline
\end{tabular}

All values represent mean $\pm S D$. Mean values bearing the different letters in the same rows are significantly different $(P<0.05)$ 
Table 3 : Mean $( \pm S D)$ carapace length and width, specific growth rate, feeding rate and survival of $P$. pelagicus juvenile fed with different fresh diets for 31 days

\begin{tabular}{llll}
\hline & & Treatment & \\
\cline { 2 - 4 } Parameters & T1 (Scad fish) & T2 (Squid) & T3 (Acetes shrimp) \\
\hline Final carapace width $(\mathrm{mm})$ & $53 . .69 \pm 3.32^{\mathrm{b}}$ & $68.02 \pm 3.51^{\mathrm{a}}$ & $51.19 \pm 3.76^{\mathrm{b}}$ \\
Final carapace length $(\mathrm{mm})$ & $26.93 \pm 1.69^{\mathrm{b}}$ & $34.11 \pm 1.78^{\mathrm{a}}$ & $25.70 \pm 1.89^{\mathrm{b}}$ \\
Initial weight $(\mathrm{g})$ & $2.46 \pm 0.01^{\mathrm{a}}$ & $2.46 \pm 0.01^{\mathrm{a}}$ & $2.46 \pm 0.01^{\mathrm{a}}$ \\
Final weight $(\mathrm{g})$ & $10.38 \pm 1.66^{\mathrm{b}}$ & $19.77 \pm 1.05^{\mathrm{a}}$ & $10.10 \pm 2.29^{\mathrm{b}}$ \\
Weight gain $(\mathrm{g})$ & $7.92 \pm 1.66^{\mathrm{b}}$ & $17.31 \pm 1.05^{\mathrm{a}}$ & $7.64 \pm 2.29^{\mathrm{b}}$ \\
Weightgain $(\%)$ & $321.95 \pm 67.49^{\mathrm{b}}$ & $703.52 \pm 42.87^{\mathrm{a}}$ & $310.43 \pm 93.10^{\mathrm{b}}$ \\
SGR & $25.55 \pm 5.36^{\mathrm{b}}$ & $55.83 \pm 3.40^{\mathrm{a}}$ & $24.63 \pm 7.38^{\mathrm{b}}$ \\
FCR & $3.94 \pm 0.89^{\mathrm{b}}$ & $2.79 \pm 0.64^{\mathrm{b}}$ & $6.22 \pm 0.89^{\mathrm{a}}$ \\
PER & $0.25 \pm 0.05^{\mathrm{b}}$ & $0.55 \pm 0.03^{\mathrm{a}}$ & $0.24 \pm 0.07^{\mathrm{b}}$ \\
FE $(\%)$ & $26.74 \pm 6.94^{\mathrm{a}}$ & $36.11 \pm 10.74^{\mathrm{a}}$ & $16.29 \pm 2.42^{\mathrm{b}}$ \\
Survival (\%) & $44.44 \pm 9.62^{\mathrm{a}}$ & $38.89 \pm 9.62^{\mathrm{a}}$ & $27.78 \pm 9.62^{\mathrm{b}}$ \\
\hline
\end{tabular}

All values represent mean $\pm S D$. Different superscript letters within a row denote significant differences $(p<0.05) ; S G R=$ specific growth rate; $F C R=$ feed conversion ratio; $\mathrm{PER}=$ protein efficiency ratio; $\mathrm{FE}(\%)=$ feed efficiency

Table 4 : Whole body composition ( $\%$ on as dry basis) of $P$. pelagicus crab juvenile fed with three selected diets

\begin{tabular}{lllll}
\hline Proximate composition & Initial crab juvenile & T1 (Scad fish) & T2 (Squid) & T3 (Acetes shrimp) \\
\hline Moisture (\%) & $58.04 \pm 0.33$ & $58.08 \pm 0.34^{\mathrm{a}}$ & $58.76 \pm 0.09^{\mathrm{a}}$ & $58.12 \pm 0.17^{\mathrm{a}}$ \\
Protein (\%) & $31.06 \pm 0.55$ & $31.12 \pm 0.27^{\mathrm{a}}$ & $31.52 \pm 0.10^{\mathrm{a}}$ & $31.09 \pm 0.20^{\mathrm{a}}$ \\
Lipid (\%) & $1.59 \pm 0.08$ & $1.64 \pm 0.18^{\mathrm{a}}$ & $1.89 \pm 0.13^{\mathrm{a}}$ & $1.06 \pm 0.18^{\mathrm{b}}$ \\
Fiber (\%) & $7.33 \pm 1.06$ & $6.45 \pm 0.19^{\mathrm{a}}$ & $6.40 \pm 0.63^{\mathrm{a}}$ & $7.24 \pm 0.21^{\mathrm{a}}$ \\
Ash (\%) & $39.59 \pm 1.44$ & $35.72 \pm 0.89^{\mathrm{a}}$ & $35.12 \pm 0.22^{\mathrm{a}}$ & $35.82 \pm 0.53^{\mathrm{a}}$ \\
PR (\%) & & $3.78 \pm 0.83^{\mathrm{a}}$ & $6.66 \pm 0.19^{\mathrm{a}}$ & $5.88 \pm 2.44^{\mathrm{a}}$ \\
LR $(\%)$ & & $3.51 \pm 1.16^{\mathrm{b}}$ & $4.77 \pm 0.50^{\mathrm{a}}$ & $3.15 \pm 2.29^{\mathrm{b}}$
\end{tabular}

All values represent mean \pm SD. Mean values bearing the same superscripts in the same row are not significantly different $(p>0.05)$; PR $(\%)=$ protein retention; $L R(\%)=$ lipid retention; Moisture $(\%)$ on as weight basis

Data analysis: All statistical analysis were conducted using one way ANOVA. The statistically significant among the treatments were considered if the $P$ value was $\leq 0.05$ ( $5 \%$ significant level) using post-hoc Duncan's test.

\section{Results and Discussion}

The water quality parameters measured throughout the experimental period are presented in Table 2. However, a significant amount of ammonia- $\mathrm{N}$ and nitrite- $\mathrm{N}$ level was observed in Acetes shrimp. The other parameters such as dissolved oxygen (DO), water temperature, $\mathrm{pH}$ and salinity were not significantly affected by different diet treatments.

Growth performance, feed utilization and survival rate of $P$. pelagicus are presented in Table 3. Carapace width and length, weight gain, SGR (\%) and PER of $P$. pelagicus juvenile fed with squid were observed significantly higher $(P<0.05)$ than those fed the scad fish and Acetes shrimps. The best FCR and FE (\%) were found significantly higher in squid diet, followed by fed with scad fish and Acetes shrimp.
Proximate composition (moisture, protein, lipid, fiber and ash) of $P$. pelagicus juvenile fed with different diets are shown in Table 4. There were no significant differences $(P>0.05)$ in moisture, fiber and ash of juveniles fed with selected diets. Lipid and lipid retention were found highest $(p<0.05)$ in juvenile crab fed with squid and lowest in crab fed with Acetes shrimp. The highest protein ( $p>0.05$ ) was also observed in squid fed group, whereas the lowest in Acetes shrimp diet treatment.

The recirculating system can be potentially used for intensive culture with limited pollutant discharge, thereby increasing fish or crustaceans production and reducing water usage as well as adverse environmental impacts (Davis and Arnold, 1998). In the present study, the average values of the physico-chemical parameters were found within suitable range reported by Seeman et al. (2015). After the administration of different feed, the level of ammonia and nitrite-nitrogen compound $(p<0.05)$ were slightly different in Acetes shrimp diet treatment; it remained within acceptable ranges for growth and survival of $P$. pelagicus juvenile. 
Several researchers have given their efforts on developing artificial diets on growth and survival rate of aquatic organisms (Catacutan, 1997; Soundarapandian, 2008). It was found that feeding efficiency, weight gain, SGR (\%) and growth of carapace width of $P$. pelagicus were significantly higher fed with squid diet. Soundarapandian et al. (2013) reported that dietary protein is required at 20 to $60 \%$ for optimum growth of crustaceans. Since all feeds used in this study contained more than minimum protein requirement of crab diet, for instance scad fish $83.33 \%$, squid $75.41 \%$ and Acetes shrimp $56.74 \%$, therefore, other factors like digestibility has also a lead role in the feeding trial (Kanazawa et al., 1970). Squid meal is recognized as highly digestible diet for many of the crustacean (Reigh, Braden and Craig, 1990; Catacutan, 1997). For this reason it has been used as a feed ingredient in this study .

In this study, the crabs weight gain was directly not only influenced by protein content of the feeds but also it digestibility. This is in agreement with the previous reports of Chayawat et al., (2008) who revealed that the crabs fed with minced fish exhibited considerably higher weight gain and specific rate than crabs fed with wet pellets and alga (seaweed) diet. They also observed that the highest and lowest growth of crabs fed with fish and seaweed, respectively. This might be for low protein and fat content of seaweed. Crustacea (2015) also found similar results in different size groups of $S$. serrata. More or less similar growth rate was also obtained in S. tranquebarica fed with Acetes sp. incorporated pellet feed and clam meat (Soundarapandian and Murugesan, 2010). Chayawat et al. (2009) in an another study reported higher specific growth rate and carapace width in blue swimming crabs fed with mixed fish and blue mussel compared to only red seaweed. No significant differences were observed between the crabs fed with diet containing $48 \%$ protein and control diet; however maximum growth was observed with the diets that contained $50 \%$ total crude protein (Sheen and Wu, 1999).

Lowest survival was recorded in crab fed Acetes shrimp; cannibalism is a major cause of low survival of crustaceans, so this trail is also not exempted from the case. . However, survival was improved by maintaining individual crabs in darkness per cultured unit in the present study as reported by several researchers (Celada et al., 1989; Minagawa, 1994; Kevrekidis, 1996). The proximate composition of juvenile in the study were not affected by rearing techniques, except the crude lipid level which were significantly higher in squid compared to scad fish and Acetes shrimp. Although the whole body protein was still high in squid fed group but it was not a significant amount, which is in agreement with studies conducted on Portunus sp. (Gokoolu and Yerlikaya, 2003), P. sanguinolentus (Siddiquie et al., 1987), Scylla serrata (Sheen, 2000) and Callinectes sapidus (Farragut, 1965).

The overall results showed that the better water quality can be maintained in the aquaculture system by RAS set up. The growth of carapace length, weight gain, SGR (\%), PER and FE
(\%) were found higher in crabs, while they fed with squid diet than the crabs fed with scad fish and Acetes shrimp, thus suggesting that incorporation of squid meal in juvenile blue swimming crab meal may produce better survival and growth.

\section{Acknowledgments}

The authors are grateful to those who have directly and indirectly contributed to this study, especially to Comas stuff, Port Dickson. This study was funded by a grant from Universiti Putra Malaysia (UPM, Project no. GP-IPB/2014/9440402).

\section{References}

Ahamed Ali, S.: Relative efficiencies of pelletized feeds compounded with different animal proteins and the effect of protein level on the growth of the prawn Penaeus indicus. Proc. Symp. Coastal Aquaculture, 1,321-328 (1982).

AOAC (Association of Official Analytical Chemists): In: Official methods of analysis of AOAC international (Ed.: P.A. Cunniff) $\left(16^{\text {th }} \mathrm{Ed}\right.$.. Arlington, Virginia, USA: AOAC International. Association of OfficialAgricultural Chemists (1997).

Arshad, A., S.B. Japar and Z. Mutaharah: Changes in diet of juvenile flower crab, Portunus pelagicus (Crustacea: Decapoda). Science Putra, 10, 13-17 (2002).

Asphama, A.I., F. Amir, A.C. Malina and Y. Fujaya: Habitat preferences of blue swimming crab (Portunus pelagicus). Aquacul. Indones., 16, 10-15(2015).

Baliao, D.D., M.A. De Los Santos and N.M. Franco: Pen culture of mud crab in mangroves. Aquaculture Extension Manual., 29, 10 pp (1999).

Catacutan, M.R.: Protein and dry matter digestibility of feedstuffs in complete diets for Penaeus monodon. In: The Fourth Asian Fisheries Forum: Proceedings of the Fourth Asian Fisheries Forum, Asian Fisheries Society (1997).

Celada, J.D., J.M. Carral, V.R. Gaudioso, C. Temiño and R. Fernández: Response of juvenile freshwater crayfish (Pacifastacus leniusculus Dana) to several fresh and artificially compounded diets. Aquaculture, 76, 67-78 (1989).

Chaiyawat, M., I. Eungrasamee and N. Raksakulthai: Quality characteristics of blue swimming crab (Portunus pelagicus, Linnaeus 1758) Meat Fed Gracilaria edulis (Gmelin) Silva. Kasetsart J.Natur. Sci., 42,522-530(2008).

Chaiyawat, M., I. Eungrasamee and N. Raksakulthai: Meat quality of blue swimming crab (Portunus pelagicus, Linnaeus 1758) fattened with different diets. Kaset. J. Nat. Sci., 43, 132-142 (2009).

Chande, A. I. and Y.D.Mgaya: Food habits of the blue swimming crab Portunus pelagicus along the coast of Dar es Salaam, Tanzania. West. Ind. Ocean J. Mar. Sci., 3, 37-42 (2004).

Cheong, H. C., U. P. D. Gunasekera and H. P. Amandakoon: Formulation of artificial feeds for mud crab culture: a preliminary biochemical, physical and biological evaluation. The Mud Crab. Bay of Bengal Programme (1992).

Crustacea, F.: Effect of feed on the growth and survival of long eyed swimming erab Podophthalmus, (October). Scientific Reports., 681 (2015).

Deniz, A.: The effects of season and sex on the nutritional quality of muscle types of blue crab Callinectes sapidus and swimming crab Portunus segnis. Natur. Engin. Sci., 1, 1-14 (2016). 
Davis, D.A. and C.R. Arnold: The design, management and production of a recirculating raceway system for the production of marine shrimp. Aquacultural Engineering,17, 193-211 (1998).

Estefanell, J., J. Socorro, F. Tuya, M. Izquierdo and J. Roo: Growth, protein retention and biochemical composition in Octopus vulgaris fed on different diets based on crustaceans and aquaculture byproducts. Aquaculture, 322-323, 91-98 (2011).

Farragut, R.N.: Proximate composition of Chesapeake Bay blue crab (Callinectes sapidus). J. Food Sci., 30, 538-544 (1965).

Gokoolu, N. and P. Yerlikaya: Determinaton of proximate composition and mineral contents of blue crab (Callinectes sapidus) and swim crab (Portunus pelagicus) caught off the Gulf of Antalya. Food Chemistry, 80, 495-498(2003).

Hall, D., S.Y. Lee and T. Meziane: Fatty acids as trophic tracers in an experimental estuarine food chain: Tracer transfer. J. Exper. Mari. Biol. Ecol., 336, 42-53 (2006).

Hyslop, E.J.: Stomach contents analysis : A review of methods and their application. J. Fish Biol., 17, 411-429 (1980).

Ikhwanuddin, M., A.D. Talpur, M.N. Azra, B.M. Azlie, Y.H. Hii and A.B. Abol-Munafi: Effects of stocking density on the survival, growth and development rate of early stages blue swimming crab, Portunus pelagicus (Linnaeus, 1758) Larvae. World App. Sci. J., 18, 379-38 (2012).

Ikhwanuddin, M., A.N. Liyana, M.N. Azra, Z. Bachok and A.B. Abolmunafi : Natural diet of blue swimming crab, Portunus pelagicus at Strait of Tebrau, Johor, Malaysia. Sains Malaysiana, 43, 37-44 (2014).

Ishak, S.D., M.S. Kamarudin, E. Ramezani-Fard, C.R. Saad and Y.A. Yusof: Effect of varying dietary carbohydrate level on growth performance, body composition and liver histology of Malaysian mahseer fingerlings. J. Environ. Biol., 37, 755-764 (2016).

Ismail, S., M.S. Kamarudin and C.R. Saad: Dietary lipid requirement of lemon fin barb hybrid. J. Environ. Biol., 37, 765-774 (2016).

Josileen, J.: Food and feeding of the blue swimmer crab, Portunus pelagicus (Linnaeus, 1758) (decapoda, brachyura) along the Coast of Mandapam, Tamil Nadu, India. Crustaceana, 84, $1169-$ 1180 (2011).

Kanazawa, A., M. Shimaya, M. Kawasaki and K. Kashiwada: Nutritional requirements of prawn. 1. Feeding on artificial diet. Bull. Japan. Soci. Scien. Fish., 36, 949-954 (1970).

Kevrekidis, K. and T. Kevrekidis: Effects of substrate on growth and survival of postlarvae and juveniles of Penaeus japonicus bate (Crustacea, Penaeidae). Oceanographic Literature Review, 9, $913(1996)$.

Kunsook, C., N. Gajaseni and N. Paphavasit: The feeding ecology of the blue swimming crab, Portunus Pelagicus (Linnaeus, 1758), at Kung Krabaen bay, Chanthaburi Province, Thailand. Tropic. Life Sci. Res., 25, 13-27 (2014).
Maheswarudu, G., J. Jose, K.R.M. Nair, M.R. Arputharaj, A. Ramakrishna, A. Vairamani and N. Ramamoorthy: Evaluation of the seed production and grow out culture of blue swimming crab Portunus pelagicus (Linnaeus, 1758) in India. Ind. J. Mar. Sci., 37, 313-321 (2008).

Minagawa, M.: Effects of photoperiod on survival, feeding and development of larvae of the red frog crab, Ranina ranina. Aquaculture, 120, 105-114 (1994).

Reigh, R.C., S.L. Braden and R.J. Craig: Apparent digestibility coefficients for common feedstuffs in formulated diets for red swamp crayfish, Procambarus clarkii. Aquaculture, 84, 321-334 (1990).

Seemann, U.B., K. Lorkowski, M.J. Slater, F. Buchholz and B.H. Buck: Growth performance of Noble Crayfish Astacus astacus in recirculating aquaculture systems. Aquac. Int., 23, 997-1012 (2015).

Sheen, S.S.: Dietary cholesterol requirement of juvenile mud crab Scylla serrata. Aquaculture, 189, 277-285 (2000).

Sheen, S.S. and S.W.Wu: The effects of dietary lipid levels on the growth response of juvenile mud crab Scylla serrata. Aquaculture, 175, 143-153 (1999).

Siddiquie, P.J.A., Z. Akbar and R. Qasim: Biochemical composition and calorific values of the three edible species of protunid crabs from Karachi [Pakistan]. Pakistan J. Sci. Indust. Res. (Pakistan)., 30, 119-121 (1987).

Soundarapandian, P.: Effect of unilateral eyestalk ablation and diets on the growth of freshwater prawn juveniles of Macrobrachium malcolmsonii (H. Milne Edwards). J. Fisher. Aqu. Sci., 3, 47-53 (2008).

Soundarapandian, P. and K.M.M.S.R. Murugesanl: Effect of feed on the biochemical composition of commercially important mud crab Scylla tranquebarica (Fabricius 1798). Int. J. Animal Vet. Adv., 2, 16-20 (2010).

Soundarapandian, P., S. Ravichandran and D. Varadharajan: Effect of feed on the growth and survival of long eyed swimming crab Podophthalmus vigil Fabricius (Crustacea: Decapoda). Scientific Reports, 2, 681 pages (2013).

Talpur, A.D., A.J. Memon, M.I. Khan, M. Ikhwanuddin, M.M.D. Daniel and A.B. Abol-Munafi: A novel of gut pathogenic bacteria of blue swimming crab Portunus pelagicus (Linneaus, 1758) and pathogenicity of Vibrio harveyia transmission agent in larval culture under hatchery conditions. Res. J. Appl. Sci., 6, 116-127 (2011).

Tina, F.W. and U. Darumas: Feed acceptability, survival and growth performance of blue swimming crab (Portunus pelagicus. L) fed with different cheaper diets. Multi-Disciplinary Edu. Global Quest, 3, (2014).

Wu, R. S. S. and P. K. S. Shin: Food segregation in three species of portunid crabs. Hydrobiologia, 362, 107-113 (1998). 